\title{
Mineralogy Controlled Dissolution of Uranium from Airborne Dust in Simulated Lung Fluids (SLFs) and Possible Health Implications
}

\author{
Eshani Hettiarachchi ${ }^{\dagger}$, Shaylene Paul ${ }^{\ddagger}$, Daniel Cadol§, Bonnie Frey"l, and Gayan \\ Rubasinghege ${ }^{*}, \dagger$ \\ †Department of Chemistry, New Mexico Tech, 801 Leroy Place, Socorro, New Mexico 87801, \\ United States \\ ‡Department of Environmental Science, Navajo Technical University, Lowerpoint Road, \\ Crownpoint, New Mexico 87313, United States \\ §Department of Earth and Environmental Science, New Mexico Tech, 801 LeRoy PI, Socorro, \\ New Mexico 87801, United States \\ "New Mexico Bureau of Geology, New Mexico Tech, 801 LeRoy PI, Socorro, New Mexico 87801, \\ United States
}

\section{Abstract}

The recent increase in cardiovascular and metabolic disease in the Navajo population residing close to the Grants Mining District (GMD) in New Mexico is suggested to be due to exposure to environmental contaminants, in particular uranium in respirable dusts. However, the chemistry of uranium-containing-dust dissolution in lung fluids and the role of mineralogy are poorly understood, as is their impact on toxic effects. The current study is focused on the dissolution of xcontaining-dust, collected from several sites near Jackpile and St. Anthony mines in the GMD, in two simulated lung fluids (SLFs): Gamble's solution (GS) and Artificial Lysosomal Fluid (ALF). We observe that the respirable dust includes uranium minerals that yield the uranyl cation, $\mathrm{UO}_{2}{ }^{2+}$, as the primary dissolved species in these fluids. Dust rich in uraninite and carnotite is more soluble in GS, which mimics interstitial conditions of the lungs. In contrast, dust with low uraninite and high kaolinite is more soluble in ALF, which simulates the alveolar macrophage environment during phagocytosis. Moreover, geochemical modeling, performed using PHREEQC, is in good agreement with our experimental results. Thus, the current study highlights the importance of site-

\footnotetext{
*Corresponding Author: G. Rubasinghege. gayan.rubasinghege@nmt.edu. Supporting Information

This material is available free of charge on the ACS Publications Web site. The Supporting Information is available free of charge on the ACS Publications website at DOI:10.1021/acs.estlett.8b00557. Map and description of dust sample collection locations; list of chemicals; simulated lung fluid compositions and description; sample characterization including graphic of procedure for preconcentration of U minerals; SEM images of samples; Langmuir-type model; graphs of particle size distributions, variation of $\mathrm{pH}$ with time, calibration curve, and dissolved $\mathrm{U}$ concentration vs time; tables of particle sizes and PM values, surface area measurement data, rates of $\mathrm{U}$ dissolution, initial mineral molar ratios, equilibrium concentrations and percentages of dissolved U; PHREEQC 3.3.8 Input data (PDF)

Notes

The authors declare no competing financial interest.
} 
specific toxicological assessments across mining districts with the focus on their mineralogical differences.

\section{Graphical Abstract}

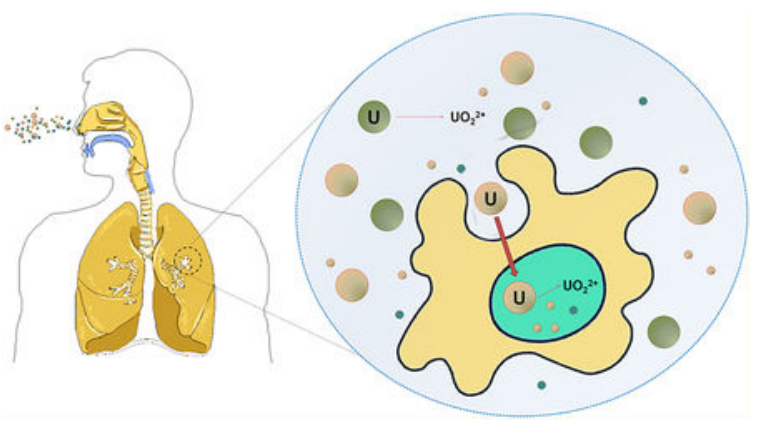

\section{INTRODUCTION}

Uranium is a naturally occurring element of which labile concentrations can increase due to human activities (e.g., mining). ${ }^{1}$ This fairly abundant heavy metal is chemically toxic $\left(\mathrm{LD}_{50}\right.$ $=14 \mathrm{mg} / \mathrm{kg}$; the lethal dose of uranium for $50 \%$ of an administered population) and can present radiological-toxicity depending on its isotopic composition and exposure route. ${ }^{1,2}$ However, considerable damage from the chemical toxicity of uranium, independent of its radioactivity, has been reported. During exposure to depleted uranium, uranyl cation $\mathrm{UO}_{2}{ }^{2+}$ binds to DNA in mammalian cells, forming a uranium-DNA (U-DNA) adduct that could cause mutations, thereby triggering a range of protein synthesis errors, some of which may lead to various cancers. ${ }^{3-6}$ A study on rat epithelial cells showed that uranium may induce significant oxidative stress and a concomitant decrease in antioxidative potential of lung tissues. ${ }^{4,7}$ Another study discusses the death of macrophages when exposed to $\mathrm{UO}_{2}{ }^{2+}$. While these studies were conducted with aqueous phase uranium, others have suggested that insoluble uranium oxide particles (e.g., $\mathrm{UO}_{2}$ ) may cause breakdown of DNA double strands in broncho-alveolar lavage cells. ${ }^{4,9,10}$

Human exposure of uranium is suggested to primarily occur through inhalation. ${ }^{1}$ Airborne particulate matter (PM) with a complex chemical composition becomes more inhalable as particle size decreases. The finer fraction of these particles can penetrate deeper into the respiratory tract, where they can be difficult to remove by the body's defense mechanisms. Particles smaller than $4 \mu \mathrm{m}\left(\mathrm{PM}_{4}\right)$ can deposit in the alveolar region of human lungs, becoming trapped in two compartments: the neutral extracellular environment in the interstitium of the lungs and the acidic environment in alveolar macrophages. ${ }^{11,12}$ More details about related lung fluids is discussed in the Supporting Information. Usually, the particles reaching the lower lungs are consumed by macrophages (phagocytized), which then move onto the mucociliary escalator for elimination. ${ }^{13}$ However, if they are dissolved due to the complexation with biological components in the lung fluids before being phagocytized, then these interactions can be detrimental to alveolar macrophages, leaving the immune system weak. ${ }^{11,12,14-18}$ To date, however, heavy metal exposure via dust inhalation and resulting health conditions have not been studied in relation to their source material. The 
mineralogy of the host deposit and the mineral species of uranium particular to that ore may, for instance, influence the consequences of inhalation. Instead, studies so far are more generalized and have primarily focused on the toxicity of uranium already in aqueous phase.

${ }^{1,3}$ This research reports on the variability in the leaching behavior of uranium from inhalable uranium-bearing dusts focusing on the mineralogy of uranium and major non-uranium minerals present in the dust. In recent decades, a notable increase in cardiovascular and metabolic diseases in the Navajo population residing close to the Grants Mining District (GMD), New Mexico, has been observed, with only limited inquiry into possible contributions from environmental contaminants, in particular uranium and vanadium. ${ }^{19}$ Our studies were carried out with aeolian transported dust collected near two uranium mines in the GMD to understand the mechanisms of uranium leaching in human lungs with the focus on dust mineralogy. The fate of uranium in dust and sediments, collected in the GMD has investigated, using two simulated lung fluids (SLFs): Gamble's solution (GS), which mimics the interstitial conditions, and artificial lysosomal fluid (ALF), which mimics the intracellular conditions in the alveolar macrophages during phagocytosis. ${ }^{20}$ In addition to laboratory simulations, PHREEQC 3.3.8, a geochemical modeling software program, was used to further investigate the effect of mineralogy on the dissolution of uranium in these SLFs.

By the combined results of laboratory studies of collected dust samples and computational -geochemical studies, we report that the mineralogy of uranium-bearing dust impacts the extent of the dissolution of uranium, before being phagocytized and during the phagocytosis, possibly leading to different toxicological fates. Thus, here we discuss leaching of uranium under these two lung conditions with respect to composition of the source material, leading to a better understanding of the mechanisms behind the cardiovascular diseases.

\section{MATERIALS AND METHODS}

\section{Dust Sample Collection.}

The dust and sediment samples were collected from five sites near Jackpile and St. Anthony mines at close proximity (within a $\sim 1.6 \mathrm{~km}$ radius) to communities in the GMD, New Mexico, during the summer of 2017 using passive dust collectors (Big Spring Number Eight dust flux samplers) at $1.5 \mathrm{~m}$ height from the surface (one dust sample from each site). Samples from Sites A, C, E, and G of Jackpile and St. Anthony mines were collected at locations with latitude and longitude of (35.8225, -107.2012), (35.7417, -107.1922), (35.8459, -107.1925), (35.8194, -107.1847), and (35.1562, -107.2940), respectively. All samples were sieved through a $500 \mu \mathrm{m}$ US standard sieve to remove organic debris from the plants prior to dissolution studies in SLFs. Samples were used as in dissolution studies, without further size fractionation. More information is provided in the Supporting Information.

\section{Standards and Chemicals.}

All chemicals were reagent grade or better and were used as received. A standard sample of $\mathrm{U}_{3} \mathrm{O}_{8}$ from National Bureau of Standards (Assay 99.9\%) was used as a model system in the 
studies. All the solutions were prepared in purified water (18.2 M $\Omega$, Milli-Q-A10). The chemicals are listed along with SLF compositions in the Supporting Information.

\section{Characterization of Dust Samples.}

Surface areas of samples were measured in a seven-point $\mathrm{N}_{2}$-Brunauer-Emmet-Teller (BET) isotherm using a Quantachrome Autosorb-1 surface area analyzer. Particle sizes were calculated using ImageJ software package, and scanning electron microscope (SEM) images of the samples were collected using a NOVA-Nano-SEM-450. Major, minor, and trace elements were quantified using inductively coupled plasma-mass spectroscopy (ICP-MS, Agilent 7900) following the EPA-3052b digestion method. ${ }^{21} \mathrm{X}$-ray diffraction (XRD) analyses of dust samples were performed in a Pananalytical X'Pert Pro diffractometer equipped with a copper source. The samples were preconcentrated prior to XRD analysis. Detailed procedures of characterization are given in the Supporting Information.

\section{Dissolution of Uranium in Simulated Lung Fluids (SLFs).}

Dissolution studies were carried out to measure total dissolved uranium concentration (TDU) using custom-built glass reactors inside a dark room. The reaction vessel had a suspension capacity of $100 \mathrm{~mL}$ with a removable airtight top. The particle loading was $\sim 0.2$ $\mathrm{g} \mathrm{L}^{-1}$ of the dust in SLF. Prior to dissolution experiments, the SLF solutions were purged with oxygen gas at $5 \mathrm{sccm}$ for $5 \mathrm{~min}$ to obtain an oxidized atmosphere. The glass reactors were equipped with a temperature probe and a standardized $\mathrm{pH}$ electrode to measure those parameters throughout the experiments. A water jacket maintained a constant temperature of $37^{\circ} \mathrm{C}$. During the experiment, the sample suspension was agitated constantly using a magnetic stirrer. Sample aliquots were periodically extracted from the reactor using a disposable syringe connected to $12 \mathrm{~cm}$ of Teflon tubing and were filtered through $0.2 \mu \mathrm{m}$ filters, prior to ICP-MS analysis, to avoid any solid carry-overs. All the dissolution studies were triplicated. The mean TDUs with one standard deviation of mean are reported.

\section{Geochemical Modeling.}

PHREEQC 3.3.8 with a modified MINTEQ database was employed in geochemical modeling. ${ }^{22}$ Maximum dissolved uranium concentration at equilibrium in an oxidized atmosphere in the two SLFs was calculated for identified uranium minerals as well as for identified total site mineralogy. For individual uranium minerals, an excess of the mineral in $100 \mathrm{~mL}$ of the lung fluid in oxidized conditions at $37^{\circ} \mathrm{C}$ was considered. For simulations with the site mineralogy, molar ratios of minerals were selected on the basis of the XRD peak intensities. The SLF input files are provided in the Supporting Information.

\section{RESULTS AND DISCUSSION}

Uranium octoxide $\left(\mathrm{U}_{3} \mathrm{O}_{8}\right)$, a highly stable major component in yellowcake and a prominent transportation and disposal species for uranium, was used as a model system. The material has not previously been studied in these two SLFs. ${ }^{23-26}$ The specific surface area of $\mathrm{U}_{3} \mathrm{O}_{8}$ sample was $0.46 \pm 0.035 \mathrm{~m}^{2} \mathrm{~g}^{-1}$. Figure 1 shows a comparison of TDU of $\mathrm{U}_{3} \mathrm{O}_{8}$ in the two SLFs, GS vs ALF. These data have been normalized to both total mass (Figure 1a) and surface area (Figure 1b) of the initial $\mathrm{U}_{3} \mathrm{O}_{8}$. The dissolution of $\mathrm{U}_{3} \mathrm{O}_{8}$ was much lower in $\mathrm{GS}$ 
than in ALF, suggesting a slight dissolution in interstitial lung environment, whereas in acidic conditions of the macrophages, simulated using ALF, $\mathrm{U}_{3} \mathrm{O}_{8}$ dissolves extensively. After $24 \mathrm{~h}, 16.2 \%$ and $0.7 \%$ of $\mathrm{U}_{3} \mathrm{O}_{8}$ dissolved in ALF and GS, respectively, indicating 23fold higher dissolution capacity in ALF. Uranium minerals are known to complex with various solution phase anions such as carbonates, phosphates, sulfates, chlorides, and vanadates. ${ }^{27-29}$ The higher uranium dissolution in ALF may have been promoted by the larger quantity and variety of ligands and the lower $\mathrm{pH}$.

Here, we present five natural dust samples, which vary by chemical composition and mineralogy, to illustrate the dissolution of inhaled U-containing-dust in lung fluids and the affect of the nonuranium-containing minerals present (Figure 2). The particle sizes of the dust samples, determined using SEM images, varied from $\sim 0.1$ to $25 \mu \mathrm{m}$ with a $\mathrm{PM}_{10}$ fraction of $\sim 91 \%$ and $\mathrm{PM}_{4}$ fraction of $\sim 65 \%$, indicating the possibility of the majority of particles reaching the alveolar region of human lungs. Therefore, the dust samples are used in dissolution studies without further size fractionation. Some of the bigger inhaled particles may be entered to the gastrointestinal tract (GI) by the clearance of mucociliary escalator. Although that is a primary exposure route, it was not considered in this study as the majority of particles may reach the alveolar region due to rather smaller particle size. ${ }^{11,12}$ More details on size distributions can be found in Figure S4 and Table S2 in the Supporting Information.

The surface areas of dust samples A, C, E, and G and the sediment sample St. Anthony were $2.10 \pm 0.09,0.77 \pm 0.14,14.5 \pm 1.02,1.77 \pm 0.59$, and $1.61 \pm 0.08 \mathrm{~m}^{2} \mathrm{~g}^{-1}$, respectively. The $\% \mathrm{U}$ of the dust samples were, respectively, $0.23 \%, 0.14 \%, 0.18 \%, 0.23 \%$, and $0.87 \%$ for sites A, C, E, and G and St. Anthony.

The mineralogy of the dust samples from XRD analysis is summarized in Table 1 and is in good agreement with mineralogy of the area. ${ }^{30}$ These data suggest that all the samples were rich with quartz and dolomite, whereas microcline, kaolinite, and calcite were present in only some of the samples. Only the St. Anthony sample contained rutile. All the samples were confirmed to contain autunite, and all of them except site A contained uraninite and coffinite.

The amount of uranium dissolved in the SLF solutions varied considerably among these samples (Figure 2a,b). Dissolution data presented in Figure 2a are normalized to their respective surface areas, and thus any differences in dissolution are due to factors that go beyond surface area effects. The average rate of uranium dissolution during the first $3 \mathrm{~h}$ and the percent uranium dissolved at the end of the 24th hour are given in Table S4. Samples from site $\mathrm{C}$ showed the highest dissolution among all the samples in both GS and ALF, at least 10-fold higher compared to the next in order, and thus fall under the high dissolution regime of TDU (Figure 2a). Samples from sites A and E produced the lowest dissolved uranium while samples from sites $\mathrm{G}$ and St. Anthony showed moderate dissolution in both SLFs.

Since these differences in TDU could arise from differences in total uranium among the solid samples, the data were normalized to their percentage U (Figure 2b). Clearly, while the 
site $\mathrm{C}$ sample stands out with the highest extent of TDU, site G and St. Anthony samples have moderate dissolution. Sites E and A samples have the lowest extent of TDU, suggesting that there are factors governing U-containing-dust dissolution in lung fluids other than surface area and amount of uranium. Source mineralogy, extent of weathering, and/or surface modifications during transport play a vital role in enhancing uranium dissolution. 27-29,31 For instance, site $\mathrm{C}$ is located immediately downwind of the mine; the source region has undergone weathering with the involvement of hydro-logical processes (Figure S1). However, sites $\mathrm{E}$ and $\mathrm{A}$ that are located within the backfilled pit and on the nearby mesa show lower extent of dissolution.

While samples from the five sites have different extents of dissolution, more uranium was dissolved from samples of sites $\mathrm{C}$ and $\mathrm{E}$ in GS than in ALF. This indicates that particle properties related to sites $\mathrm{C}$ and $\mathrm{E}$ favor higher TDU in conditions similar to interstitium in the deep lungs than in conditions found in alveolar macrophages during phagocytosis. The TDU in the site C sample was $~ 1.5$-fold more soluble in GS (11\%) than in ALF (8\%) after $24 \mathrm{~h}$ of the process (Figure 2 and Table S4). Similarly, site E sample showed $\sim 1.7$-fold higher solubility in GS (0.3\%) compared to that in $\operatorname{ALF}(0.2 \%)$. In contrast, samples of sites A and G and St. Anthony showed higher TDU in ALF than in GS, comparable to the dissolution trends observed for $\mathrm{U}_{3} \mathrm{O}_{8}$. Sites $\mathrm{A}$ and $\mathrm{G}$ and St. Anthony samples were $~ 1.2$, $\sim 1.6$, and $\sim 2.6$-fold more soluble in ALF than in GS, respectively. The mineral dissolution in fluids is primarily driven by surface complexation, by either ligand-controlled or protonpromoted mechanisms in which complexation is highly dependent on the particle mineralogy. ${ }^{32-35}$ As U(IV) is comparatively insoluble, the sparingly soluble mineral uraninite $\left(\mathrm{UO}_{2}\right)$ is a major uranium precipitate in nature. ${ }^{29}$ In contrast to $\mathrm{U}(\mathrm{IV}), \mathrm{U}(\mathrm{VI})$ containing minerals are more soluble and its solubility increases in the presence of carbonates at a $\mathrm{pH}$ above 5.5. ${ }^{27}$ Varying environmental conditions influence the oxidation state of uranium, and thus, the uranium minerals formed. In addition to carbonates, as mentioned earlier, other important ligands such as phosphate, sulfate, or vanadate either from the dusts or from the body fluid can affect the dissolution of uranium minerals. Thus, the TDU differences in the two SLFs likely arise from the mineralogical differences in the dust itself.

A geochemical modeling, carried out as a comparative study with above minerals identified. These results are provided in the Supporting Information (Table S5-S8). The uranium dissolutions, modeled introducing one mineral at a time, suggested that autunite, carnotite, tyuyamunite, and uraninite were more soluble in GS than in ALF, with TDU in GS/ALF ratios of 1.58, 16.11, 17.79, and 1.01, respectively. The minerals schoepite, torbernite, coffinite, and uranophane were more soluble in ALF than in GS, with TDU in GS/ALF ratios of $0.58,0.26,0.95$, and 0.26 , respectively. Total uranium dissolution, modeled as a multimineral assemblage with identified site-specific minerals (Table S8), further confirmed higher dissolution of uranium minerals in GS than in ALF for sites C and E, whereas others were simulated to have higher dissolution in ALF than in GS. Collectively, these results suggest that the types and quantities of minerals present control uranium dissolution. For instance, carnotite, which is present in sites $\mathrm{C}$ and $\mathrm{E}$, may enhance the dissolution in GS. Further, the dissolution of autunite may have controlled by the other minerals, suggesting possible common ion effects. According to modeled output combined with experimental data, there was no dissolution of autunite in ALF in sites A, C, and E, while its dissolution is 
very low in St. Anthony ( $\sim 0.02 \%$ of the initial amount). However, autunite dissolves $\sim 16 \%$ of its initial mass in site G. In GS, the dissolution of autunite is $4 \%, 100 \%$, and $10 \%$ of its initial mass in sites A, C, and E while no dissolution for the sites St. Anthony and G. Therefore, it is apparent that the dissolution of uranium containing minerals in the lung fluids is controlled by the total mineralogy of the site. It is not clear why certain uranium minerals dissolve more in GS than in ALF. However, the oxidation state of $U$ in these minerals is either IV or VI and that may influence surface-mediated redox reactions. Other metal ions (i.e., $\mathrm{Ca}^{2+}, \mathrm{K}^{+}, \mathrm{V}(\mathrm{V})$ ) and anions (i.e., vanadate, silicate, or phosphate) in the mineral lattice may also play a role in surface-complexation and ligand-controlled dissolution. Additionally, depending on the amount of basic minerals (i.e., calcite, dolomite) in the dust, the $\mathrm{pH}$ of the lung fluids may slightly vary leading to some variations in uranium dissolution. The solution $\mathrm{pH}$ was monitored in the current study and reported in Figure S5 in the Supporting Information. In GS, the $\mathrm{pH}$ increased by $\sim 0.2$ units during the $24 \mathrm{~h}$ period whereas no significant change observed in the ALF. However, there was no significant variation ( $\mathrm{p}>0.05$ ) in the postdissolution $\mathrm{pH}$ among the different dust samples, in both ALF and GS, indicating little or no influence on the observed variations in the uranium dissolution. Further research is suggested to understand the driving mechanisms behind mineralogy-driven differences in uranium dissolution.

The primary dissolved uranium species in the SLFs was confirmed as uranyl cation, $\mathrm{UO}_{2}{ }^{2+}$, using the uranyl-curcumin-Triton-X system at $\mathrm{pH} 4$ with colorimetric analysis. ${ }^{36}$ Experimental details and results are provided in the Supporting Information. Moreover, the consistency of mineralogy-driven differences in uranium dissolution throughout the seasons was verified with a second batch of dust, collected during winter of 2017 (Figure S7).

In summary, for the first time, we investigated the dissolution of respirable uranium from a variety of mineral dust particles using two SLFs that mimic two different physiological conditions. Our results suggest that uranium-bearing dust can be dissolved in interstitial lung fluids and/or during phagocytosis, with the potential of mobile uranium compounds (primarily $\mathrm{UO}_{2}{ }^{2+}$ ) entering the bloodstream. The mineralogy of the source material appears to unequally influence uranium dissolution in the two different lung conditions; uranyl vanadate minerals such as carnotite and tyuyamunite, as well as uraninite and autunite, are shown to be more soluble in interstitial conditions. However, minerals such as torbernite, schoepite, coffinite, and uranophane are more soluble in a simulated alveolar macrophage environment. The extent of uranium dissolution in the two different lung fluids heavily depends on the total mineralogy of the dust itself, suggesting the strong common ion effects. In particular, the amount of uraninite has shown to increase the dissolution in the interstitial conditions of the deep lungs. This suggests that the toxicological assessments on these mining lands should be site-specific rather than applied generally. Depending on the particle mineralogy, in certain sites more uranium can be dissolved in interstitial fluids and/or alveolar macrophages, primarily forming potentially toxic $\mathrm{UO}_{2}{ }^{2+} \cdot{ }^{3-6}$ Overall, dust inhalation followed by dissolution may cause adverse toxic effects due to the compositional changes (i.e., $\mathrm{pH}$, speciation, and ionic strength) in the lungs. Therefore, understanding the behavior of inhaled U-containing-dust in these mining areas with the specific focus on site mineralogy is vitally important. The knowledge from the current study may lead to further 
research in understanding the radiation-independent toxicity of uranium as it relates to the mineralogy of the inhaled dusts.

\section{Supplementary Material}

Refer to Web version on PubMed Central for supplementary material.

\section{ACKNOWLEDGMENTS}

Research reported in this publication was partially supported by an Institutional Development Award (IDeA) from the National Institute of General Medical Sciences of the National Institutes of Health under grant number P20GM103451 and NM EPSCoR under the National Science Foundation/EPSCoR Award No. IIA-1301346. The authors thank Alexandra Pearce for joining in the summer dust sample collection, Dr. Virginia McLemore and Marcus Silva for providing sediment samples from St. Anthony Mine as well as Dr. Virgil Lueth and Kelsey McNamara at the New Mexico Bureau of Geology, Reid Brown for the total elemental analysis of the dusts samples, and Maria Troyer at Environmental Engineering for collecting SEM images at the CINT user facility of Sandia National Laboratories.

\section{REFERENCES}

(1). Asic A; Kurtovic-Kozaric A; Besic L; Mehinovic L; Hasic A; Kozaric M; Hukic M; Marjanovic D Chemical toxicity and radioactivity of depleted uranium: The evidence from in vivo and in vitro studies. Environ. Res 2017, 156, 665-673. [PubMed: 28472753]

(2). Briner W The toxicity of depleted uranium. Int. J. Environ. Res. Public Health 2010, 7, 303-313. [PubMed: 20195447]

(3). Stearns DM; Yazzie M; Bradley AS; Coryell VH; Shelley JT; Ashby A; Asplund CS; Lantz RC Uranyl acetate induces hprt mutations and uranium-DNA adducts in Chinese Hamster Ovary EM9 Cells. Mutagenesis 2005, 20, 417-423. [PubMed: 16195314]

(4). Pereira S; Camilleri V; Floriani M; Cavalie I; Garnier-Laplace J; Adam-Guillermin C Genotoxicity of uranium contamination in embryonic zebrafish cells. Aquat. Toxicol 2012, 109, 11-16. [PubMed: 22204984]

(5). Hsieh P; Yamane K DNA mismatch repair: Molecular mechanism, cancer, and ageing. Mech. Ageing Dev. 2008, 129, 391-407. [PubMed: 18406444]

(6). Schneider J; Phillips M; Yamini P; Dork T; Woitowitz H-J ATM gene mutations in former uranium miners of SDAG Wismut: A pilot study. Oncol. Rep 2007, 17, 477-482. [PubMed: 17203191]

(7). Periyakaruppan A; Kumar F; Sarkar S; Sharma CS; Ramesh GT Uranium induces oxidative stress in lung epithelial cells. Arch. Toxicol 2007, 81, 389-395. [PubMed: 17124605]

(8). Orona NS; Tasat DR Uranyl nitrate-exposed rat alveolar macrophages cell death: Influence of superoxide anion and TNF a mediators. Toxicol. Appl. Pharmacol 2012, 261, 309-316. [PubMed: 22561334]

(9). Monleau M; De Méo M; Frelon S; Paquet F; Donnadieu-Claraz M; Dumenil G; Chazel V Distribution and genotoxic effects after successive exposure to different uranium oxide particles inhaled by rats. Inhalation Toxicol 2006, 18, 885-894.

(10). Thiébault C; Carrière M; Milgram S; Simon A; Avoscan L; Gouget B Uranium induces apoptosis and is genotoxic to normal rat kidney (NRK-52E) proximal cells. Toxicol. Sci 2007, 98, 479487. [PubMed: 17522072]

(11). Guney M; Bourges CMJ; Chapuis RP; Zagury GJ Lung bioaccessibility of As, Cu, Fe, Mn, Ni, $\mathrm{Pb}$, and $\mathrm{Zn}$ in fine fraction $(<20 \mu \mathrm{m})$ from contaminated soils and mine tailings. Sci. Total Environ 2017, 579, 378-386. [PubMed: 27887839]

(12). Kastury F; Smith E; Juhasz AL A critical review of approaches and limitations of inhalation bioavailability and bioaccessibility of metal(loid)s from ambient particulate matter or dust. Sci. Total Environ 2017, 574, 1054-1074. [PubMed: 27672736]

(13). Stine K; Brown T Principles of Toxicology, 1st ed.; CRC Lewis: New York, 2010. 
(14). Chen LC; Lippmann M Effects of metals within ambient air particulate matter (PM) on human health. Inhalation Toxicol. 2009, 21, 1-31.

(15). Dean JR; Elom NI; Entwistle JA Use of simulated epithelial lung fluid in assessing the human health risk of $\mathrm{Pb}$ in urban street dust. Sci. Total Environ 2017, 579, 387-395. [PubMed: 27887829]

(16). Mercer RR; Scabilloni JF; Wang L; Battelli LA; Antonini JM; Roberts JR; Qian Y; Sisler JD; Castranova V; Porter DW; et al. The fate of inhaled nanoparticles: detection and measurement by enhanced dark-field microscopy. Toxicol. Pathol 2018, 46, 28-46. [PubMed: 28929951]

(17). Colombo C; Monhemius AJ; Plant JA Platinum, palladium and rhodium release from vehicle exhaust catalysts and road dust exposed to simulated lung fluids. Ecotoxicol. Environ. Saf 2008, 71, 722-730. [PubMed: 18206235]

(18). Adar SD; Filigrana PA; Clements N; Peel JL Ambient coarse particulate matter and human health: A systematic review and meta-analysis. Curr. Environ. Heal. Rep 2014, 1, 258-274.

(19). Zychowski KE; Kodali V; Harmon M; Sanchez B; Suarez Y; Cerrato JM; Muttil P; Brearley A; Ali AM; Lin Y; et al. Respirable uranyl-vanadate containing particulate matter derived from a legacy uranium mine site exhibits potentiated cardiopulmonary toxicity. Toxicol. Sci 2018, 164, 101-114. [PubMed: 29660078]

(20). Pelfrêne A; Cave MR; Wragg J; Douay F In vitro investigations of human bioaccessibility from reference materials using simulated lung fluids. Int. J. Environ. Res. Public Health 2017, 14, 112.

(21). Environmental Protection Agency. EPA Method 3050B (SW-846): Acid digestion of sediments, sludges, and soils; EPA, 1996.

(22). Parkhurst D; Appelo C Description of input and examples for PHREEQC version 3-A computer program for speciation, batch-reaction, one-dimensional transport, and inverse geochemical calculations; USGS, 2013.

(23). Grenthe I; Drozdzynski J; Fujino T; Buck EC; Albrecht-Schmitt TE; Wolf SF Uranium. In The Chemistry of the Actinide and Transactinide Elements, Vol. 1; Morse LR, Edelstein NM, Fuger J, Katz JJ, Eds.; Springer: Amsterdam, 2011; pp 253-698.

(24). Dias Da Cunha KM; Lima C; Barrosleite CV; Santos M; Carneiro L; Lima RMG Uranium oxide solubility in simulated lung fluids. J. Occup. Environ. Hyg 2011, 8, D51-D56. [PubMed: 21667368]

(25). Li W; Skinner R; Megna K; Chen J; Perera S; Murimboh J; Waller E; Erhardt L; Cornett RJ In vitro dissolution study of uranium dioxide and uranium ore with different particle sizes in simulated lung fluid. J. Radioanal. Nucl. Chem 2009, 279, 209-218.

(26). Sdraulig S; Franich R; Tinker RA; Solomon S; O’Brien R; Johnston PN In vitro dissolution studies of uranium bearing material in simulated lung fluid. J. Environ. Radioact 2008, 99, 527538. [PubMed: 17949865]

(27). Cumberland SA; Douglas G; Grice K; Moreau JW Uranium mobility in organic matter-rich sediments: A review of geological and geochemical processes. Earth-Sci. Rev 2016, 159, 160185.

(28). Osman AAA; Geipel G; Barkleit A; Bernhard G Uranium(VI) binding forms in selected human body fluids: thermodynamic calculations versus spectroscopic measurements. Chem. Res. Toxicol 2015, 28, 238-247. [PubMed: 25562669]

(29). Bone SE; Dynes JJ; Cliff J; Bargar JR Uranium(IV) adsorption by natural organic matter in anoxic sediments. Proc. Natl. Acad. Sci. U. S. A 2017, 114, 711-716. [PubMed: 28069941]

(30). Wilton T Uranium deposits at the Cebolleta project, Laguna mining district, Cibola County, New Mexico. New Mex. Geol 2017, 39, 1-10.

(31). Prospero JM Long-range transport of mineral dust in the global atmosphere: Impact of African dust on the environment of the southeastern United States. Proc. Natl. Acad. Sci. U. S. A 1999, 96, 3396-3403. [PubMed: 10097049]

(32). Yoo JC; Park SM; Yoon GS; Tsang DCW; Baek K Effects of lead mineralogy on soil washing enhanced by ferric salts as extracting and oxidizing agents. Chemosphere 2017, 185, 501-508. [PubMed: 28715761]

(33). Refaey Y; Jansen B; Parsons JR; de Voogt P; Bagnis S; Markus A; El-Shater AH; El-Haddad AA; Kalbitz K Effects of clay minerals, hydroxides, and timing of dissolved organic matter addition 
on the competitive sorption of copper, nickel, and zinc: A column experiment. J. Environ. Manage 2017, 187, 273-285. [PubMed: 27914349]

(34). Troyer LD; Maillot F; Wang Z; Wang Z; Mehta VS; Giammar DE; Catalano JG Effect of phosphate on U(VI) sorption to montmorillonite: Ternary complexation and precipitation barriers. Geochim. Cosmochim. Acta 2016, 175, 86-99.

(35). Wiederhold JG; Kraemer SM; Teutsch N; Borer PM; Halliday AN; Kretzschmar R Iron isotope fractionation during proton-promoted, ligand-controlled, and reductive dissolution of goethite. Environ. Sci. Technol 2006, 40, 3787-3793. [PubMed: 16830543]

(36). Zhu JH; Zhao X; Yang J; Tan YT; Zhang L; Liu SP; Liu ZF; Hu XL Selective colorimetric and fluorescent quenching determination of uranyl ion via its complexation with curcumin. Spectrochim. Acta, Part A 2016, 159, 146-150. 
(a)

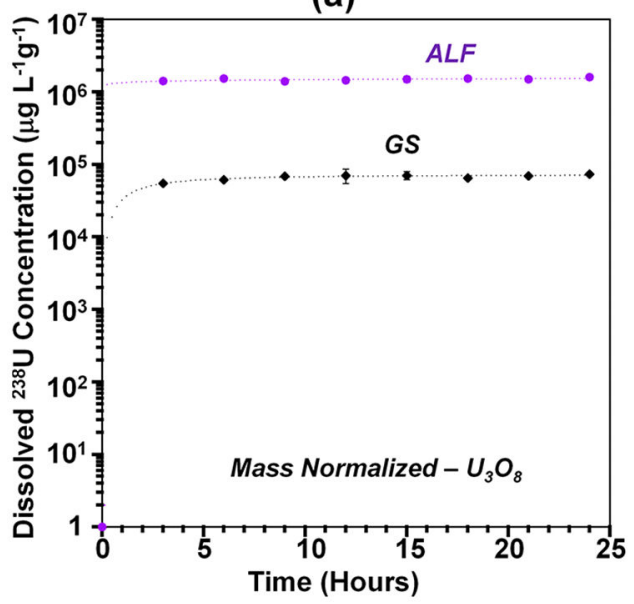

(b)

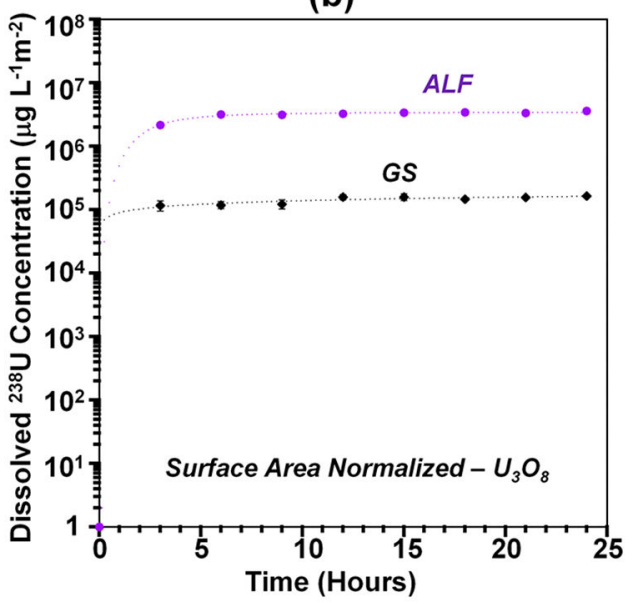

Figure 1.

Dissolution of uranium (TDU) as a function of time from $\mathrm{U}_{3} \mathrm{O}_{8}$ standard in the two simulated lung fluids. The data are (a) mass normalized and (b) surface area normalized and fitted to Langmuir type model and presented with a log scaled Y axis. The Langmuir type model is explained in the Supporting Information. 
(a)

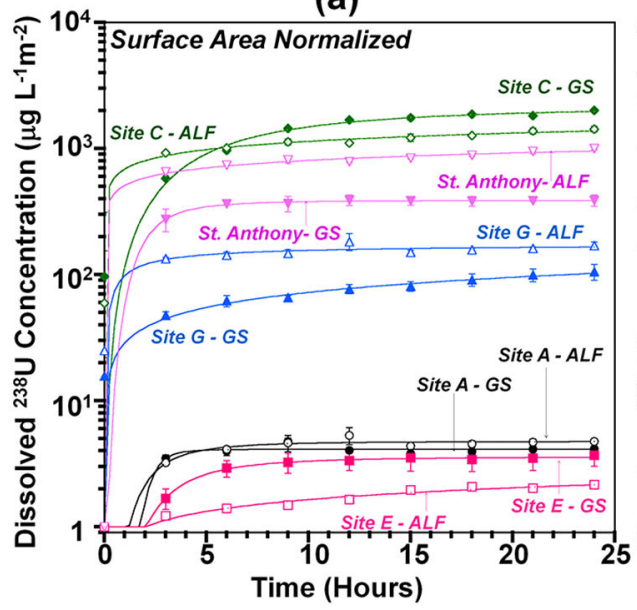

(b)

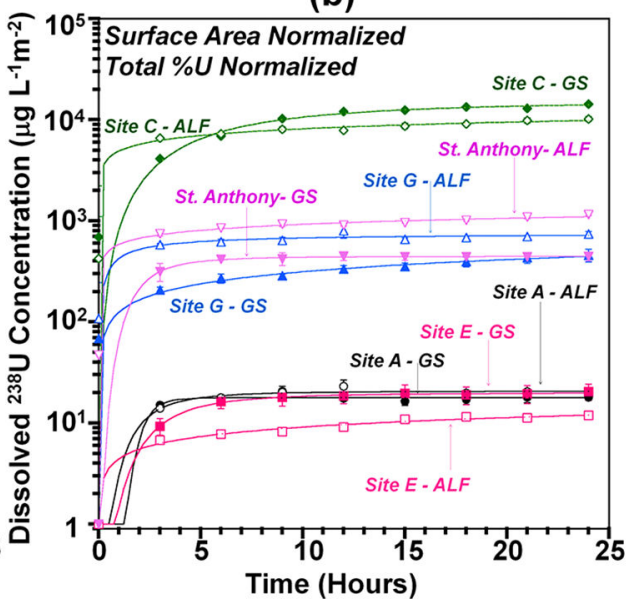

Figure 2.

Dissolution of total uranium (TDU) as a function of time from the five sites A, C, E, and G and St. Anthony in the two SLFs as a function of time. (a) Normalized to surface area. (b) Normalized to both surface area and total \%U. Data are fitted to the Langmuir type model and presented with a log scaled Y axis. 
